\title{
Analysis of the Influence of Listed Companies' Share Arrangement on Business Performance
}

\author{
Zhou xiao wei; Li bowen \\ Shanxi Normal University \\ Xian, China \\ 731228148@qq.com
}

\begin{abstract}
At present, as an integral part of the market, the company is playing a more and more important role in the wave of economic globalization. Corporate decision makers, managers, and supervisors are particularly important in corporate competition. Regression analysis is conducted on panel data of shareholdings of general managers, senior managers, and supervisors. The correspondence between Residual Rights of Control and Residual Claim is important. That is, the board of directors, general manager, senior management personnel, and supervisors has shares that help improve the company's performance. At the same time, they are affected by corporate incentive goals and incentive mechanisms, but directors, general manager, senior management personnel, and supervisors should each have the number of shares that need to be optimized and discussed.
\end{abstract}

Keywords-Residual Rights of Control; Residual Claim; Nonhuman capital; Incentives

\section{INTRODUCTION}

In the process of global economic development, companies are playing an increasingly important role and have become an important force in promoting technological innovation, economic growth, and social stability. Faced with more and more fierce competition in the global market and higher and higher consumer demand for products and services, Chinese enterprises are in a period of transformation and upgrading, and they need to innovate. Enterprises face an uncertain future. Corporate decision makers, managers, and supervisors play an increasingly important role. A good company, enterprise's decision-makers, managers and supervisors must ensure that they truly have entrepreneurial talents, but also make the people who control the enterprise have the enthusiasm to create value for the shareholders. Therefore, in the face of an uncertain future, it will be particularly important who will take the helm and who will bear the risks for the company. Therefore, the ownership arrangement of the company must be rationally arranged. The corporate governance structure must also solve the problems and incentives of the operators. problem.

In domestic and foreign research, the focus is on the impact of changes in governance structure on business performance, and it has not been studied from the perspectives of corporate ownership arrangements, decision-makers and managers, and supervisors' choices and incentives. Some of the earlier published articles focused mainly on theoretical analysis. For example, in 1998, He Jun had analyzed the ownership structure of listed companies and conducted indepth research on internal control. In 1995, Zhang Chunlin studied the moral hazard in the principal-agent relationship and conducted a series of evaluations. The articles with relatively late publication state the classification of stateowned shares and tradable shares and their impact on corporate performance and value. In these studies, there is also no analysis of residual control rights and ownership, but only analysis of measurement. The level. In addition, Chen Xiao et al. conducted in-depth research on three industries in different competitive environments in 2000, and conducted research on the company's performance in different environments under different circumstances. There are also some articles on the study of the proportion of shares held by the largest shareholder and whether it is part-time manager's influence on company performance. For example, Huang Zuhui and Sun Yongxiang proposed that the shareholding ratio of the largest shareholder affects Tobin's Q value. Feng Genfu, Han Bing, and Yan Bing (2002) have studied the corporate governance structure in different directions. They mainly consider the factors that influence the concentration of listed companies' equity. One problem that has not been studied in these literatures is that it does not address corporate governance in the face of uncertainties in listed companies, where genuine "manufacturing risk" decision makers and managers and supervisors correspond to the real risk-taking shareholders. The impact on corporate performance has not been analyzed and interpreted from the ownership of the company, and it has not highlighted the choice and incentive role of the corporate governance structure among decision makers, managers and supervisors. This paper attempts to study the decision-makers, managers, and supervisors of listed companies under the residual ownership sharing system from the perspective of the correspondence between residual ownership and residual control rights. The influence of the proportion of shares on business performance. 


\section{THE ESTABLISHMENT OF AN EMPIRICAL MODEL}

According to the optimal arrangement, the ownership and residual control rights are unified and corresponding. The chairman, general manager, and senior management of the company have "natural" residual control rights. When these decision makers and managers also become shareholders Whether it is the unity and correspondence between the remaining ownership and the remaining control rights, then whether this kind of ownership arrangement actually generates business performance and how much impact it will generate requires us to carry out empirical research and analysis. Therefore, this paper will use Tobin's q-values of nonfinancial private companies listed on the Shanghai and Shenzhen stock exchanges as indicators of the company's performance, that is, as the interpreted variable TBQit, the board chairman, general manager, and senior management of these listed companies. The proportion of shares held by personnel and supervisors, rate1it, rate2it, rate3it, rate4it, are used as explanatory variables. At this point, a regression model is established: Uit

TBQit $=c+$ a1rate 1 it + a2rate $2 \mathrm{i}+$ a3rate $3 i t+a 4 r a t e 4 i t+$

In the model, the index it represents the i-th company in year $t$; $y$ is the proxy variable of company performance, $c$ is the intercept, a1, a2, ..., a4 is the regression coefficient, Uit, is a random term.

\section{SAMPLE AND VARIABLE DESCRIPTION}

\section{A. Sample selection}

The corporate governance structure data used in this paper comes from companies listed on the Shanghai and Shenzhen stock exchanges in the Guotai database. The data spans all non-financial private listed companies from 2012 to 2016.In the sample selection process, the following principles are mainly followed: First, because of the characteristics of the financial company itself, in the previous studies, the listed companies in this category of companies were seldom studied. Second, because state-owned listed companies are very special on the ownership arrangement, they are not considered in this article. Third, in order to make the company's behavior relatively mature, only relatively long-listed companies will be studied in this article. Fourth, in order to ensure the continuity of the data, companies with more than five years of continuous data must be selected. Fifth, because the share price of foreign shares is different from the share price of public A shares, it is convenient to eliminate companies that own $\mathrm{B}$ shares or $\mathrm{H}$ shares. Sixth, to remove companies that have financial anomalies or have been in continuous loss for more than two years. This paper builds a panel of non-financial companies that include information from at least five consecutive years between 2012 and 2016.

\section{B. Variable description}

The variable description is shown in Table 1

TABLE I VARIABLE DESCRIPTION

\begin{tabular}{|c|c|c|}
\hline variable & Variable representation & Definition of variables \\
\hline Tobin's q-value & TBQ & TBQ=Tobin's q-value \\
\hline Chairman's shareholding & rate $_{1}$ & rate $_{1}=$ Chairman's shareholding \\
\hline General Manager's shareholding & rate $_{2}$ & $\begin{array}{ll}\text { rate }_{2}=\text { General } & \text { Manager's } \\
\text { shareholding } & \end{array}$ \\
\hline Senior management shareholding & rate $_{3}$ & $\begin{array}{l}\text { rate }_{3}=\text { Senior management } \\
\text { shareholding }\end{array}$ \\
\hline Supervisor shareholding & rate $_{4}$ & rate $_{4}=$ Supervisor shareholding \\
\hline
\end{tabular}

\section{POSITIVE PROCESS, RESULTS AND ANALYSIS}

\section{A. Panel data unit root test}

In order to determine the stationarity of each variable, a unit root test is performed before the panel data is estimated. In order to determine the stationarity of each variable, a unit root test is performed before the panel data is estimated. In this paper, we use the four methods of LLC test, IPS test, ADFFisher $\mathrm{CH}$ test and PP-Fisher $\mathrm{CH}$ test to perform unit root test of panel data. The test results are shown in Table 2. 
TABLE II TEST RESULTS

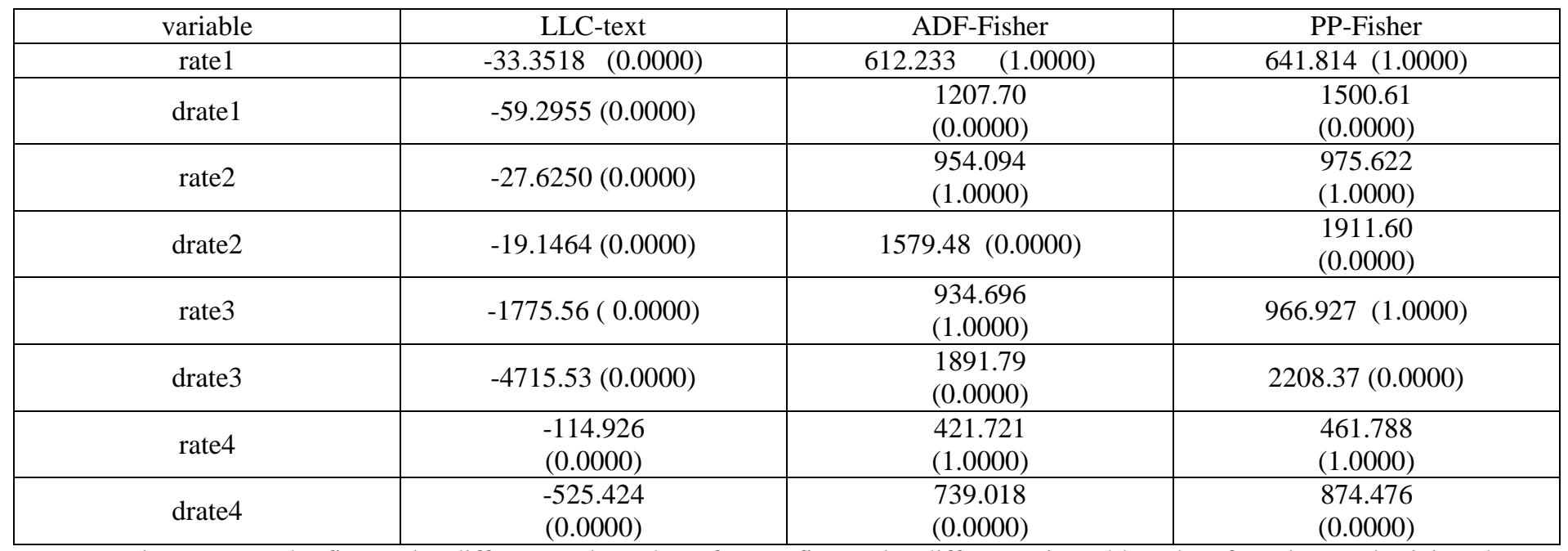

Note:d represents the first-order difference, the value of $\mathrm{P}$ in the brackets is the corresponding statistic, and the test form includes both the intercept item and the trend item.

According to Table 3, it can be seen that the unit root test results of various variables show that the three methods of LLC test for homogeneous panels and ADF-Fisher and PPFisher tests for heterogeneous panels are significant at $1 \%$. The level of sexuality shows that the selected variable after the first-order difference is stable. Therefore, by synthesizing the results of the above table, it can be considered that each variable in the regression model is a first-order monotonic sequence.

B. Analysis of regression results

TABLE III REGRESSION RESULTS

\begin{tabular}{|c|c|c|c|c|}
\hline Variable & Coefficient & Std. Error & t-Statistic & Prob. \\
\hline & & & & \\
\hline $\mathrm{C}$ & 2.105388 & 0.035605 & 59.13218 & 0.0000 \\
\hline RATE1 & 0.001436 & 0.002909 & 0.493595 & 0.0616 \\
\hline RATE2 & 0.003110 & 0.002734 & 1.137300 & 0.0455 \\
\hline RATE3 & 0.005460 & 0.002079 & 2.626613 & 0.0087 \\
\hline RATE4 & 0.013437 & 0.018246 & 0.736441 & 0.0615 \\
\hline \multicolumn{5}{|l|}{$\begin{array}{c}\text { Fixed Effects } \\
(\text { Period })\end{array}$} \\
\hline $20102-\mathrm{C}$ & -0.029035 & & & \\
\hline $2013-\mathrm{C}$ & -0.043428 & & & \\
\hline $2014-\mathrm{C}$ & 0.158597 & & & \\
\hline $2015-\mathrm{C}$ & -0.065185 & & & \\
\hline $2016-C$ & -0.000749 & & & \\
\hline \multirow{2}{*}{\multicolumn{5}{|c|}{$\begin{array}{l}\text { Effects Specification } \\
\text { Period fixed (dummy } \\
\text { variables) }\end{array}$}} \\
\hline & & & & \\
\hline R-squared & 0.571767 & & & \\
\hline Adjusted R-squared & 0.559751 & & & \\
\hline Prob (F-statistic) & 0.000000 & & & \\
\hline
\end{tabular}

According to the regression results shown in Table 4-2 above, all statistics passed the significance test at the significance level of $10 \%, \mathrm{R} 2$ was 0.57 , and the F statistic also passed the significance test. Although the model goodness of 
fit is not high enough, there is a certain correlation between the variables of the model as a whole, so the correlation analysis can be performed based on the regression results.

Based on the above regression results, it can be seen that the holding of shares by the chairman, general manager, senior managers, and supervisors has a significant positive effect on the growth of corporate performance. The elasticity of the factors held by the chairman, general manager, senior managers, and supervisors on the growth of the company's performance is $0.0014,0.0031,0.0055$, and 0.0134 , respectively, which means that the shareholding of the chairman of the company increases by 1 percentage point. Tobin's performance is measured by the factors. The $q$ value will increase by 0.0014 ; the shareholding ratio of the general manager will increase by 1 percentage point; the Tobin's $\mathrm{q}$ value to measure the company's performance will increase by 0.0031 ; the share of senior management personnel will increase by 1 percentage point; the Tobin's $q$ value to measure corporate performance will be increased. It will increase by 0.0055 ; the share of supervisors will increase by 1 percentage point, and the Tobin's $\mathrm{q}$ value, which measures corporate performance, will increase by 0.0134 .

\section{V.CONCLUSION AND SUGGESTION}

\section{A. Conclusion}

Through the study of this paper, it is found that the performance of the company's chairman, general manager, senior management personnel, supervisors, and corporate performance is as follows:

TBQ $=2.11+0.0014$ rate $_{1}+0.0031$ rate $_{2+} 0.0055$ rate $_{3+}$ 0.0134 rate $_{4}$

Among them, TBQ reflects the performance of the company, rate1 represents the shareholding of the chairman, rate 2 represents the shareholding of the general manager, rate 3 represents the proportion of senior managers, and rate 4 represents the ratio of the supervisor. From the above function, it can be seen that when corporate decision makers, managers, and supervisors own shares, they have a positive impact on improving corporate performance. When the remaining ownership of the enterprise corresponds to the residual control right, that is, the manufacturer of the risk is also the bearer of the risk. This is a good corporate governance structure, which ensures the decision makers, managers, and supervisors who control the enterprise. Enthusiasm creates value for the interests of shareholders and the development of the company. When these are decision-makers, managers, and supervisors of human capital, when they own shares, his interests are in line with the interests of the company's companies. This can be seen as a conversion of this part of human capital to fixed capital, because they have become risky. Recipients, their commitments will become more credible, and they will be more motivated to make positive decisions. Regardless of how these decision-makers, managers, and supervisors who own stocks have acquired their shares, they have become part of their wealth and have tied this wealth to the development of the company. From the perspective of personal wealth and the choice of owning the company's shares, these decision-makers, managers, and supervisors who own shares notice that they themselves are optimistic about the future development of the company and have more reason to believe that they have the ability to operate. Therefore, it can be seen from the results of empirical results that allowing decision makers, managers, and supervisors to own shares can improve business performance. At the same time, we see from the regression results that the shares of the chairman, general manager, senior management personnel, and supervisors increased by $1 \%$ respectively, and their impact on Tobin's q value increased in turn. Among them supervisors' shareholdings have the greatest impact on Tobin's q-value, and we need to pay attention to them. We should strengthen the design of the regulatory revenue incentive mechanism. The general manager's shareholding has no significant effect on Tobin's q-value, so we need to establish a sound manager incentive system. Strengthen the intensity and dynamism of experiencing incentives. However, this model can not tell whether the chairman, general manager, senior management personnel, and supervisors should each have the appropriate number of shares. It is good to arrange the optimization of the shares between them.

Through the results of the regression, we can also find that the impact of each variable on corporate performance is not significant. For example, if the number of shares of the chairman increases by $1 \%$, Tobin's q-value increases by only 0.011436 , and the share of senior management members increases by $1 \%$. Tobin's $\mathrm{q}$ value only increased by 0.054460.Our interpretation of this result can be divided into the following points: (1) The development of a company depends not only on the corporate governance structure of the company itself, but also on the stock arrangement of decision makers, managers, and supervisors. The same is affected by the economic development status of the entire country and even the world; (2) When the chairman, general manager, senior manager, and supervisor all own shares, they have the right to vote in the face of uncertain circumstances, but we The relative size of their shares is unclear, that is, it is not clear who has the right to make the final decision; (3) The incentive targets set by the company are different, leading to the company's pursuit of long-term goals or increase in market share. Large scale and so on will affect the impact of the current stage on corporate performance; (4) The diversity of corporate incentive mechanisms is also responsible for the company's performance and decision-makers, managers and supervisors of the relationship between the arrangements of shares; (5) different stages of corporate development It will affect the influence of the arrangement of the chairman, general manager, senior management personnel, and supervisors on the performance of the company in this model.

\section{B. Suggestion}

Through the theoretical analysis and empirical analysis of the impact of the company's shareholding arrangements on corporate performance by corporate decision makers, managers, and supervisors, we can see that the arrangement of corporate ownership has a very important significance and role. Shareholders and corporate decision makers, managers, and supervision The enterprise ownership arrangement of these human capital owners depends on the game power of each capital on the one hand, but it can also emphasize the role of 
one party. Therefore, the following suggestions are proposed based on the inclusion of shareholders and human capital in the scope of corporate governance: (1) In the process of examining and approving the establishment of a new listed company, the relevant organization needs to guide the listed company to rationalize the equity structure and examine its rationality; (2) Relevant organizations need to categorize and standardize the ownership standards for different enterprises with different capital roles. (3) Establish and promote the marketization and dynamism of managers' incentive systems within the company, and optimize the recruitment system for managers to achieve Convergence, to strengthen managers in the manager's market competition; (4) to strengthen the optimization of the incentive system for regulators; (5) to enrich and optimize corporate incentive objectives and incentive systems.

\section{REFERENCES}

[1] Ahn,S.,DJ Denis, DK Denis, "Leverage and Investment in Diversified Firms," Working paper, 2003.

[2] Christie, William G, 1994, Are Dividend Omissions T ruly the Cruelest Cut of All, Journal of Financial and Quantitative Analysis 29, No 3, September, 459-480.

[3] Denis, David and Skinner, Douglas, 1994, Reversal of Fortune Dividend Signaling and the Disappearance of Sustained Earnings Growth, Journal of Financial Economics, 40,341-371.

[4] Li xin chun, Yang xue ru, Jiang yue xin,Hu xiao hong.Insider ownership and enterprise value: A study of chinese private listed companies [J]. Economic Research Journal, 2008(11). (In Chinese)

[5] Xu li ping,Xin yu,Chen gong meng.The influence of equity concentration and equity checks and balances on the companies operating performance [J]. Economic Research Journal, 2006 (1). (In Chinese) 